\title{
Showing they care, but about what? Does corporate social responsibility show companies have a nice side or that they are merely adapting to suit their environment?
}

\author{
Henry Hillman \\ Bristol Law School, \\ University of the West of England, \\ Coldhabour Lane, Bristol, BS16 1QY, UK \\ E-mail: Henryhillman@hotmail.com
}

\begin{abstract}
This paper takes Unilever as an example of a multi-national corporation (MNC) and considers the environment it exists within. Specific attention is paid to the concept of corporate social responsibility (CSR); a definition is sought and reasons for its development are discussed. Significance is placed on globalisation, not specifically of business but of society, and the increased connectedness of the world's populations through the internet and social media. Questions are raised as to the motives of companies who engage in CSR initiatives but it is noted that genuine good can come of CSR.
\end{abstract}

Keywords: multi-national corporations; MNCs; corporate social responsibility; CSR; globalisation; social media; corporate governance; non-governmental organisations; NGOs.

Reference to this paper should be made as follows: Hillman, H. (2013) 'Showing they care, but about what? Does corporate social responsibility show companies have a nice side or that they are merely adapting to suit their environment?', Int. J. Liability and Scientific Enquiry, Vol. 6, Nos. 1/2/3, pp.156-167.

Biographical notes: Henry Hillman is an LLM student at the University of the West of England. Having completed his LLB degree at the same institution, he returned to study on the International Banking and Finance LLM. This paper formed part of his written assessments in corporate governance and corporate social responsibility and he expresses his thanks to Dr. Sabine Hassler for her excellent tutelage. His research interests are the regulation of multinational companies and the impact of the internet on the law.

\section{Introduction}

In the modern world the behaviour of a company is not judged exclusively by whether it complies with the law, the effect of globalisation means consumers, the press and non-governmental organisations (NGOs) are more able to exert pressure on companies. Increasingly connected populations can facilitate wide reaching reactions to the behaviour of multi-national corporations $(\mathrm{MNCs})^{1}$ via the internet for relatively little 
cost. The law has also experienced a degree of globalisation; international guidelines exist in numerous areas, providing model laws and standards for MNCs to adhere to. ${ }^{2}$

In this climate, the compliance of Unilever Group will be explored from three perspectives, the laws in existence, the regulations which must be followed, and the cultural influences on the company. The consideration of the laws influencing MNCs will explore national and international laws; here the increased global efforts to draft law will be analysed. The regulatory settings include legally enforceable regulation as well as the development of voluntary codes. Finally the social setting in which the company exists is discussed, this will include the non-legal implications MNCs face due to the current cultural norms and behaviour of the world population, specifically consumers, the press and NGOs. Firstly, a brief history and description of Unilever must be provided.

It will be seen that contemporary MNC regulation is not limited to the laws of the jurisdiction the MNC is operating in, the development of the internet, more informed consumers and social networking means strong self-regulation is required. While in the past holding companies like Unilever could be largely anonymous and their operations could continue out of sight of the consumer, in the 21 st century all companies can be held to account by individuals with few resources, though the internet and social networks.

\section{Unilever}

Unilever the product of the merger in 1930; the Dutch company 'Naamlooze Vennootschap Margarine Unie' and 'Lever Brothers Limited' of the UK joined in a business merger rather than a legal merger. ${ }^{3}$ The business merger was chosen to avoid punitive taxes, and two companies still exist; 'Unilever PLC' in the UK and 'Unilever NV' in the Netherlands.

Figure 1 Legal structure of unilever ${ }^{4}$ (see online version for colours)

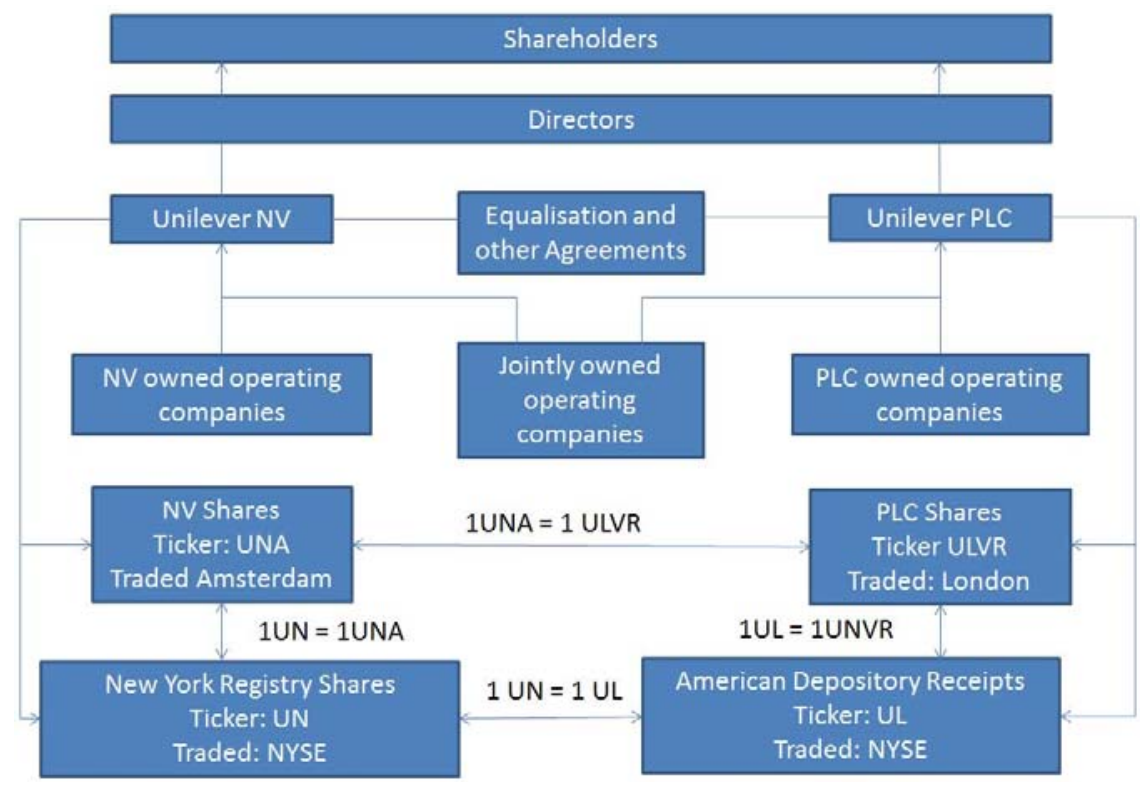


Figure 1 shows the structure of the Unilever Group. The shares of the two parent companies to the Unilever Group are valued equally, wherever the share is purchased. Unilever NV and Unilever PLC are traded in Amsterdam and London stock exchanges respectively; additionally they are both traded on the New York Stock Exchange. The companies operate as a single entity, sharing all their assets via various agreements signed in the merger, this provides for the sharing of brands and technology, as well as a shared board of directors.

The Unilever Group is a holding corporation, the group claim to own more than 400 brands $^{5}$ producing consumer goods including food, drink, cleaning, and health and beauty products. ${ }^{6}$ Unilever employ over 173,000 people, ${ }^{7}$ selling products in more than 190 countries, ${ }^{8}$ and the company achieved a turnover of $€ 51$ billion in 2012. ${ }^{9}$ Unilever's legal structure is different to many companies, but the two parent companies are required to comply with UK and Dutch corporate governance legislation.

\section{$3 \quad$ Legal setting}

In incorporating a company, the company must comply with the laws of the jurisdiction they have registered in. This includes various formalities surrounding reporting of profits and specific duties to be completed by designated members of staff. As well as this a company must ensure they practice good corporate governance.

An agreed definition of corporate governance proves difficult. Collins dictionary simply defines it as "the balance of control between the stakeholders, managers and directors of an organisation". ${ }^{10}$ Commentators have gone further than this; proposing it distributes the "rights and responsibilities among different participants in the corporation" 11 and "spells out the rules and procedures for making decisions on corporate affairs". ${ }^{12}$ Corporate governance helps provide safeguards to investors, without a framework of control there is little stopping those running the company from taking company money for themselves.

Corporate governance has developed predominantly in recent decades; high profile collapses as a result of fraud can be seen as a catalyst for this. Infamous examples include Polly Peck in the UK ${ }^{13}$ and Enron in the USA. Enron filed for bankruptcy in $2001^{14}$ and as it collapsed large scale fraud and embezzlement became apparent, ${ }^{15}$ investors were left to bear the losses. Polly Peck was run by Asil Nadir for over ten years during which he stole approximately $£ 150$ million from the company; ${ }^{16}$ the shareholders of the company were the victims of Nadir's crimes. Cases such as these and others like Worldcom and Coloroll provided the impetus for improved corporate governance provisions. The UK commissioned three major reports in the $1990 \mathrm{~s},{ }^{17}$ the Cadbury Committee in $1992,{ }^{18}$ the Greenbury Committee in $1995^{19}$ and the Hampel Committee in $1998{ }^{20}$ Subsequent reform came through the Corporate Governance Code in the $\mathrm{UK}^{21}$ and through the Sarbanes-Oxley $\mathrm{Act}^{22}$ in the USA. The Enron collapse in particular was influential as it demonstrated that even the largest of companies could be destroyed if safeguards are not in place. The UK's approach has formed the starting point for other countries in writing their own codes. ${ }^{23}$ The aim of the UK Code is to "facilitate effective, entrepreneurial and prudent management that can deliver the long-term success of [a] company". ${ }^{24}$

The legal structure of Unilever Group means it must comply with the corporate governance laws of two jurisdictions, fortunately for Unilever the two sets of laws are similar. Both the UK and Netherlands operate under a 'comply or explain' principle, ${ }^{25}$ the 
philosophy behind this principle is to allow flexibility as not all companies are the same. The Dutch and UK codes are markedly similar because both jurisdictions are members of the EU; as such they should have codes which comply with Directive 2006/46/EC. ${ }^{26}$

\section{Regulatory setting}

Incorporating a company creates a legal person; based on this principle the legal person takes on the same responsibility for its actions as individuals, and to this end a company should be liable for its actions just as an individual would be. Furthermore a company acting in a foreign territory should abide by the laws of the territory in which they are in. With relation to the actions of MNCs outside of their home states, questions can arise over behaviour which is legal in the state they are active but would be illegal in their home state. However, regulating and pursuing MNCs under the law is more complex than pursuing a natural legal person; a human being cannot claim one of its arms to be a separate entity. The concept of a company being a legal person is adopted within the EU legislation; specifically Article 54 of the Treaty on the Functioning of the European Union $^{27}$ (TFEU). A company with a "registered office, central administration or principal place of business within the Union shall... be treated in the same way as natural persons". An example of its application can be seen in Centros Ltd and Erhverus-og Selkabsstyrelsen, ${ }^{28}$ demonstrating its use by a company exercising its right to register in another Member State and for that Member State to accept the laws of incorporation of the company's home state. Article 54 should allow EU law to hold companies to account as legal persons but sometimes it is difficult to ascertain which company is the correct company to pursue. The litigation in the wake of the Bhopal gas leak demonstrates the difficulties of pursuing an elusive company, ${ }^{29}$ Union Carbide tried to distance themselves from the event by claiming the Indian subsidiary was a separate company, this was to minimise damages as the Indian subsidiary had less money with which to pay any settlement. $^{30}$

A further issue arises where a company is adhering to the laws of a jurisdiction but those laws are of a low standard; the MNC is technically operating within the law, but concerns are raised from the developed world that environmental and human rights violations are occurring which many jurisdictions legislate against. This can be seen publically, most clearly through the work of high profile NGOs such as Friends of the Earth, ${ }^{31}$ and in relation to the Niger Delta the Socio-Economic Rights and Accountability Project (SERAP). ${ }^{32}$ The Bhopal case demonstrates the difficulty in pursuing an MNC; the Niger Delta violations highlight the increased complexity where a government is corrupt and as such complicit. ${ }^{33}$ With relatively little action possible in relation to dictating the laws a country should introduce, the onus has been placed on companies abiding by international standards.

The Organisation for Economic Co-operation and Development (OECD) provides guidelines for MNC's on acceptable behaviour, developed by Professor John Ruggie. ${ }^{34}$ These guidelines codify standards expected of MNCs wherever they are active. The aim is to avoid situations similar to that caused by the oil industry to the Niger Delta, where corrupt officials and complicit oil companies committed environmental and human rights violations while mining and exporting crude oil. ${ }^{35}$ The guidelines are helpful, but they are vague in places and arguably state the obvious, however they are a step in the right direction. However it could be argued that the fact such basic standards need to be set is a 
sad reflection of MNCs. The OECD has 34 member states which encourage the MNCs of their jurisdictions to comply, this highlights weakness in the guidelines; they are voluntary and MNCs do not face any enforcement measures if they do not sign up or they breach the guidelines.

The OECD is not the only organisation which has produced a set of guidelines, the UN provides guidance in relation to human rights, ${ }^{36}$ and its subsidiary the International Labour Organisation also provides guidelines in relation to labour standards. ${ }^{37}$ The various codes can act against each other in that they can clutter the field, this is exacerbated by company led codes which they write and impose on themselves. Self-written codes may be beneficial to a company as they can take greater control over the obligations they place on themselves.

Unilever provides an example of an MNC adopting various measures consistent with self-regulation and increased standards of care. Unilever promotes its activity on its website, ${ }^{38}$ including outlining their Purpose and Principles ${ }^{39}$ which the company operates by, Unilever's Supplier Code ${ }^{40}$ detailing the behaviour expected of Unilever's suppliers, and the website also contains information regarding Unilever's approach to sustainability. ${ }^{41}$

The development and adoption of international codes has coincided with the development of the internet and increased global communications. As technology has improved more and more people are able to communicate with people they could not communicate with before. As such the reputation of an MNC can be affected by behaviour previously out of sight of its consumer base. With this increase in consumers informed as to the behaviour of MNCs, MNCs are increasingly being expected to exceed the minimum standards set by regulation; the development of corporate social responsibility (CSR) has coincided with the growth of globalisation and the internet which will be seen though discussion of the social climate MNCs operate in.

\section{Social setting}

To assess the entire social setting in which Unilever operates is not possible within this paper, such an examination would arguably be better suited to a sociology paper in order to do it justice. This analysis will be limited to the concept of CSR and the influences on its development. A narrow reading of the issue would conclude that CSR is not a legal issue, despite there being many codified standards they are not universally agreed, and the obligations are not binding ergo there are no consequences for breaching them. While it is true that it is not possible to directly link any consequence to a company breaching a voluntary obligation, MNCs must consider their voluntary agreements in a similar way to which nations agree to international treaties and codes.

Academics have been struggling to define CSR for decades and from a variety of starting points. Friedman was sceptical of CSR, arguing it was "fundamentally subversive" ${ }^{, 42}$ and that corporate officials accepting social responsibility undermines free society. ${ }^{43}$ However, at a similar time commentators such as McGuire were open to the idea of corporations having social responsibilities ${ }^{44}$ and in 1971 the Committee for Economic Development (CED) suggested a company's responsibility could be grouped into circles as seen in Figure 2. 
Figure 2 Three concentric circle approach proposed by $\mathrm{CED}^{45}$ (see online version for colours)

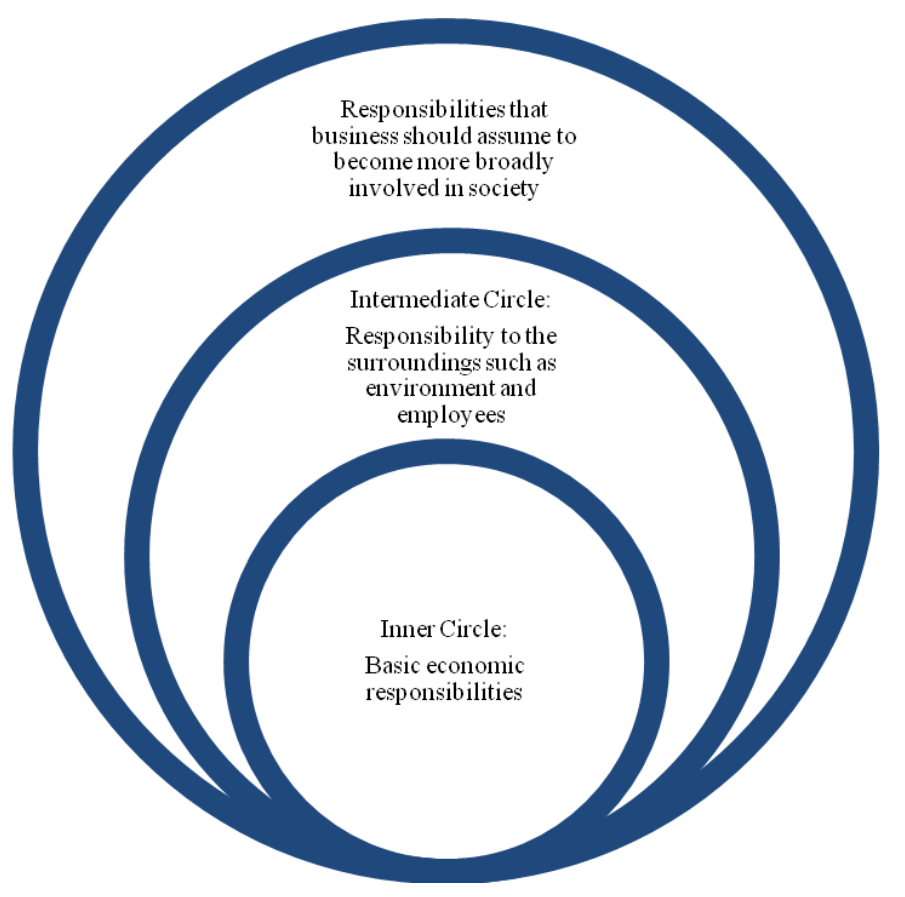

The CED concluded that a company's responsibilities could be categorised based on the distance from its central economic concerns. Davis and Blomstrom did not deem CSR to be entirely separate from the traditional responsibilities of a company, it was seen to be incorporated into these responsibilities and the development of additional responsibilities was endorsed. ${ }^{46} \mathrm{CSR}$ is different for every MNC; Carroll proposed a four-stage process, arguing that a company's total social responsibility was the sum of all its responsibilities; "The social responsibility of business encompasses the economic, legal, ethical and discretionary expectations that society has of organisations at a given time." 47

It can be seen from the early literature that CSR was viewed from a business performance perspective, indeed Ankerman and Bauer criticised the term 'social responsibility', arguing the emphasis should be on responding to social demands. This highlights a potential criticism of CSR; it is a business tool rather than the philanthropic activity it is portrayed as. Corporations must engage in CSR due to the climate they operate in, but some corporations do this so as to remain marketable rather than because they genuinely care.

More recently Silberhorn and Warren have assessed CSR from a corporation's perspective; $^{48}$ in 2007 they found that despite its philanthropic beginnings CSR is considered principally with performance in mind, followed by corporate values and finally stakeholder pressure. ${ }^{49}$ Companies will prioritise responsibilities for which they will suffer a direct consequence; a study by Pinkston and Carroll concluded legal responsibilities to be the highest-ranking CSR component for UK and German countries, ${ }^{50}$ with similar results in the USA. ${ }^{51}$ Silberhorn and Warren argue the legal and economic responsibilities produce a minimum threshold for CSR, but the philanthropy was declining. O'Dwyer also identifies self-interest in CSR; he argues that three 
overlapping rationales drive CSR; proactive enlightened self-interest, reactive enlightened self-interest and finally obligations and duties. ${ }^{52}$ This is consistent with corporate goals and shows CSR as a means of competition between companies, they must proactively seek out new initiatives, react to competitors' moves and comply with the law. The resources a company devotes to CSR will depend on a variety of factors; Maclagan found the a directors personal values will influence a company's CSR policies, but the driving force according to Pinkston and Carroll, ${ }^{53}$ as well as Levy and Shatto, ${ }^{54}$ was company size and monetary resources dictate the level of funding given the CSR. This is logical but also is consistent with the competitive nature of CSR; the more money a company has, the more it may spend on CSR in order to gain an advantage over its rivals.

Defining CSR is difficult; it changes over time and from company to company. Similarly to model laws and behavioural codes, the over complication of the area has led to many companies defining CSR themselves. There is a caveat to this proactive step; a company may define CSR itself so it can control the responsibilities it wishes to take on.

As explored above, CSR has been described as reactive and relevant to the environment companies work in, the reasons for its development are found in the changes to that environment. Companies arguably led the development of globalisation in search of resources, cheap labour and market opportunities; but it is the globalisation of society that is heavily influencing the CSR behaviour of corporations. The development of the internet has improved communication immeasurably; this has allowed for the development of worldwide social networks such as Facebook ${ }^{55}$ and increase the spread of information. Improvements in communication have in turn increased the levels of awareness amongst consumers, who are now able to easily discover the actions of companies. It is arguably this spread of information that has forced companies to consider behaviour towards the people they affect and their surroundings. In accepting this companies have then taken this on as their responsibility, and must fulfil their responsibilities as their consumers can discover failings and spread these findings easily. Campaigns can easily gain momentum and force companies to change behaviour; examples include a campaign from Greenpeace against Waitrose causing it to end a partnership with Shell, ${ }^{56}$ and Friends of the Earth's aforementioned pursuit of Shell in the Niger Delta. ${ }^{57}$

Unilever do no attempt to define CSR, in fact their literature avoids the term, this approach allows them to determine their responsibilities, following their Purpose and Principles $^{58}$ which are published on their website and put focus on their sustainable living plan. ${ }^{59}$ Unilever displays O'Dwyer's 'proactive enlightened self-interest' by developing their own initiatives, such as the Lifebuoy ${ }^{\mathrm{TM}}$ soap project, ${ }^{60}$ and the Pureit ${ }^{\mathrm{TM}}$ water purifiers. ${ }^{61}$ Unilever also displays examples of reactive enlightened self-interest through joining established projects such as the Fairtrade Foundation ${ }^{62}$ and working with charities such as WWF, ${ }^{63}$ Rainforest Alliance ${ }^{64}$ and Oxfam. ${ }^{65}$

In addition to the sustainability plan, Unilever set themselves goals and have published a report outlining their progress, ${ }^{66}$ appearing to add to their obligations. In this report they outline the 57 goals they have set themselves, it is claimed that they have achieved 1 , are on track with 49 , being on schedule with 6 and have failed to achieve 1 goal. They boast a reduction in waste and an increase in sustainably sourced materials, ${ }^{67}$ as well as reaching millions of people with their Lifebuoy ${ }^{\mathrm{TM}}$ and Pureit ${ }^{\mathrm{TM}}$ products, 48 million and 35 million respectively. These results are stated by the company alone, they are not verified independently. Despite this, Unilever's approach to 
sustainability is noteworthy due to the way in which they calculate their impact; it is calculated to include the impact their products have on the environment both in production and when used by the consumer, this accounted for $68 \%$ of Unilever's carbon footprint. ${ }^{68}$ Unilever could have calculated a $68 \%$ lower carbon footprint for their company. However, this is likely to be a deliberate move by Unilever and demonstrates how CSR is arguably a corporate game, in Unilever including the use of their products they can make their operation appear more sustainable. A further advantage of this approach is to share the responsibility, while the majority of CSR concerns companies changing their behaviour; this approach encourages consumers to take part as well. Thus, Unilever can argue that if a consumer believes Unilever should care about the environment, then that consumer should also care about the environment themselves.

Unilever have also utilised the increase in consumer awareness and adapted their products accordingly, for example they have introduced concentrated detergents to minimise packaging and developed their products to clean at lower temperatures. These steps widen the range of products Unilever can offer, embracing the concerns of their consumers; arguably satisfying Ankerman and Bauer's opinion that CSR should encompass responding to the market ${ }^{69}$ and could even be seen as capitalism as it utilises a gap in the market to increase profit.

CSR reporting is not solely undertaken by the company engaging in it, there are various organisations which award rankings to company's CSR achievements ${ }^{70}$ which a will be displayed on a company's website. ${ }^{71}$ Such initiatives highlight a criticism of CSR reporting, like the standards applied to codes, there are not agreed levels to which CSR report must reach. It is highly unlikely that many consumers could place CSR awards into any kind of hierarchy, or identify the standard to which a company is judged. They are merely badges a company wears for which there very little consumers can do to differentiate them. A further sceptical element to CSR is the consultancy business which has grown with it; services are offered to companies so as to develop and tailor a CSR programme to suit them, the epitome of the Ankerman and Bauer corporate responsiveness concept, developing to the market. $^{72}$

\section{Conclusions}

The setting in which companies operate has changed over time with the development of globalisation, technological advances and the increased awareness of the consumer. Corporate governance has developed in the wake of high profile scandals; the law is reactive and the scandals provided the incentive for change. While the laws of developed countries are largely adequate to regulate the activities of MNCs, increased awareness of environmental disasters and human rights violations has highlighted the deficiencies of developing countries legal systems. This has led to the rise of international codes of conduct, which while being inherently well meaning have failed to set an accepted standard. The lack of an agreed code has arguably caused the development of further codes and initiatives to achieve an agreed code; this has lead to a proliferation of codes and as such caused companies to create their own but in the process add to the issue.

Arguably the biggest driver of change in MNC behaviour, aside from legal influence, will be economic considerations. Unilever pursue a public CSR programme and produce products in line with this, improving their performance in the process. This is because their customers increasingly demand ethically sound products, by embracing this and 
challenging consumers to reduce their carbon footprint, Unilever are improving their economic performance.

\section{Notes}

1 Sometimes referred to as transnational companies, international corporations or multinational enterprises (MNEs) but all these terms generally refer to the same concept, a company active in multiple jurisdictions or countries. From this point MNCs will be used in the interests of consistency.

2 Such as the OECD guidelines for MNCs: OECD, Consultation on the Guidelines for Multinational Enterprises and the UN 'Protect, Respect and Remedy' Framework [online] $\mathrm{http} / / / \mathrm{www}$. oecd.org/daf/inv/mne/consultationontheguidelinesformultinationalenterprisesandth eunprotectrespectandremedyframework.htm (accessed 3 April 2013); the FATF recommendations on money laundering and counter terrorist financing: Financial Action Taskforce, FATF Recommendations 2012 [online] http://www.fatf-gafi.org/media/fatf/ documents/recommendations/pdfs/FATF Recommendations.pdf (accessed 27 April 2013); and the Commonwealth model laws on cybercrime: The Commonwealth, Model Law on Computer and Computer Related Crime [online] http://www.thecommonwealth.org/shared _asp_files/uploadedfiles/\%7BDA109CD2-5204-4FAB-AA77-86970A639B05\%7D_ Computer\%20Crime.pdf (accessed 27 April 2013).

3 Unilever, Understanding Unilever $N V \&$ PLC Shares [online] http://www.unilever.com/ investorrelations/shareholder_info/understanding_nvplc_shares/index.aspx (accessed 1 April 2013).

4 Figure 1: produced using data found at Unilever, Understanding Unilever $N V$ \& $P L C$ Shares [online] http://www.unilever.com/investorrelations/shareholder_info/understanding _ nvplc shares/index.aspx (accessed 1 April 2013).

5 Unilever, About Us [online] http://www.unilever.com/aboutus/introductiontounilever/ (accessed 1 April 2013).

6 Unilever, About Us [online] http://www.unilever.com/aboutus/introductiontounilever/ (accessed 1 April 2013).

7 Unilever, Unilever Facts [online] http://www.unilever.com/aboutus/introductiontounilever/ unileverataglance/ (accessed 1 April 2013).

8 Unilever, Unilever Facts [online] http://www.unilever.com/aboutus/introductiontounilever/ unileverataglance/ (accessed 1 April 2013).

9 Calendar year figure: Unilever, Unilever Facts [online] http://www.unilever.com/aboutus/ introductiontounilever/unileverataglance/ (accessed 1 April 2013).

10 Collins, Corporate Governance [online] http://www.collinsdictionary.com/dictionary/english/ corporate-governance (accessed 2 April 2013).

11 Wajeeh, I.A. and Muneeza, A. (2012) 'Strategic corporate governance for sustainable mutual development', Int. JLM, Vol. 54, No. 3, p.197.

12 Wajeeh, I.A. and Muneeza, A. (2012) 'Strategic corporate governance for sustainable mutual development', Int. JLM, Vol. 54, No. 3, p.197.

13 BBC News, How Asil Nadir Stole Polly Peck's Millions [online] http://www.bbc.co.uk/news/ uk-19161940 (accessed 1 April 2013).

14 BBC News, Enron Files for Bankruptcy [online] http://news.bbc.co.uk/1/hi/business/1688550. stm (accessed 2 April 2013).

15 BBC News, $Q \& A$ : The Enron Case [online] http://news.bbc.co.uk/1/hi/business/3398913. stm (accessed 2 April 2013).

16 BBC News, How Asil Nadir Stole Polly Peck's Millions [online] http://www.bbc.co.uk/ news/uk-19161940 (accessed 2 April 2013). 
17 Goergen, M. (2012) International Corporate Governance, p.129, Pearson, Harlow, England.

18 Cadbury, A. (1992) Report of the Committee on the Financial Aspects of Corporate Governance, Gee \& Co Ltd., London, England.

19 Greenbury, R. (1995) Report of a Study Group Chaired by Sir Richard Greenbury, Gee \& Co Ltd., London, England.

20 Hampel Committee (1998) Final Report - Committee on Corporate Governance, Gee Publishing Ltd., London, England.

21 Financial Reporting Council, The UK Corporate Governance Code [online] http://www.frc. org.uk/Our-Work/Publications/Corporate-Governance/UK-Corporate-Governance-CodeSeptember-2012.aspx (accessed 1 April 2013).

22 Pub L 107-204 Stat 745.

23 Goergen, M. (2012) International Corporate Governance, p.129, Pearson, Harlow, England.

24 UK: Financial Reporting Council, The UK Corporate Governance Code [online] http://www.frc.org.uk/Our-Work/Publications/Corporate-Governance/UK-CorporateGovernance-Code-September-2012.aspx (accessed 1 April 2013).

25 UK: Financial Reporting Council, The UK Corporate Governance Code [online] http://www.frc.org.uk/Our-Work/Publications/Corporate-Governance/UK-CorporateGovernance-Code-September-2012.aspx (accessed 1 April 2013) at p.4.

Netherlands: Corporate Governance Code Monitoring Committee, Dutch Corporate Governance Code [online] http://commissiecorporategovernance.nl/download/?id=606> (accessed 1 April 2013) at p.5.

26 Council Directive 2006/46/EC of 14 June amending Council Directives 78/660/EEC on the annual accounts of certain types of companies, 83/349/EEC on consolidated accounts, $86 / 635 / \mathrm{EEC}$ on the annual accounts and consolidated accounts of banks and other financial institutions and 91/674/EEC on the annual accounts and consolidated accounts of insurance undertakings [2006] OJ L 224/1.

27 Consolidated Version of the Treaty on the Functioning of the European Union (TFEU) [2012] OJ C326 art 54.

28 Centros Ltd v Erhverus-og Selkabsstyrelsen [1999] ECR I-1450, Case C-212/97.

29 Muchlinski, P. (1987) 'The Bhopal case: controlling ultra hazardous industrial activities undertaken by foreign investors', $M L R$, Vol. 50, No. 5, p.545.

30 Muchlinski, P. (1987) 'The Bhopal case: controlling ultra hazardous industrial activities undertaken by foreign investors', $M L R$, Vol. 50, No. 5, p.545.

31 Friends of the Earth, What We Do [online] http://www.foei.org/en/what-we-do (accessed 16 April 2013).

32 Socio-Economic Rights and Accountability Project, Who We Are [online] http://www.serapnigeria.org/who-we-are/ (accessed 05/08/2013).

33 For detailed accounts of the Niger Delta violations and the effect on the Ogoni people, see: Ocheje, P.D. (2001) 'Law and social change: a socio-legal analysis of Nigeria's corrupt practices and other related offences act 2000', Journal of African Law, Vol. 45, No. 2, p.173; Human Rights Watch, The Price of Oil [online] http://www.guardian.co.uk/business/2012/ aug/19/shell-spending-security-nigeria-leak (accessed 29 December 2012); and Shell, The Ogoni Issue [online] http://www.shell.com.ng/environment-society/ogoni.html (accessed 3 January 2013). The most recent court decision on the issue was Socio-Economic Rights and Accountability Project (SERAP) v. Federal Republic of Nigeria, Judgement $\mathrm{N}^{\circ}$ $\mathrm{ECW} / \mathrm{CCJ} / \mathrm{JUD} / 18 / 12$

34 OECD, Consultation on the Guidelines for Multinational Enterprises and the UN 'Protect, Respect and Remedy' Framework [online] http://www.oecd.org/daf/inv/mne/ consultationontheguidelinesformultinationalenterprisesandtheunprotectrespectandremedyfram ework.htm (accessed 3 April 2013). 
35 For detailed commentary, see: Ocheje, P.D. (2001) 'Law and social change: a socio-legal analysis of Nigeria's corrupt practices and other related offences act 2000', Journal of African Law, Vol. 45, No. 2, p.173; Friends of the Earth, Behind the Shine: The Other Shell Report [online] http://www.foe.co.uk/resource/reports/behind shine.pdf (accessed 3 January 2013); Shell, The Ogoni Issue [online] http://www.shell.com.ng/environment-society/ogoni.html (accessed 3 January 2013); and Human Rights Watch, The Price of Oil [online] http://www.guardian.co.uk/business/2012/aug/19/shell-spending-security-nigeria-leak (accessed 29 December 2012)

36 Business Human Rights Resource Centre, Guiding Principles on Business and Human Rights: Implementing United Nations 'Protect, Respect and Remedy' Framework [online] http://www.business-humanrights.org/media/documents/ruggie/ruggie-guiding-principles-21mar-2011.pdf (accessed 3 April 2013).

37 International Labour Organisation, Labour Standards [online] http://www.ilo.org/global/ standards/lang--en/index.htm (accessed 3 April 2013).

38 Unilever, About Us [online] http://www.unilever.com/aboutus/ (accessed 2 April 2013).

39 Unilever, Purpose and Principles [online] http://www.unilever.com/aboutus/ (accessed 2 April 2013).

40 Unilever, Unilever's Supplier Code [online] http://www.unilever.com/aboutus/ purposeandprinciples/supplier-code/ (accessed 2 April 2013).

41 Unilever, Our Sustainability Strategy [online] http://www.unilever.com/sustainable-living/ ourapproach/oursustainabilitystrategy/index.aspx (accessed 2 April 2013).

42 Friedman, M. (1962) Capitalism and Freedom, University Press of Chicago, Chicago, USA.

43 Friedman, M. (1962) Capitalism and Freedom, University Press of Chicago, Chicago, USA.

44 McGuire, J.W. (1963) Business and Society, McGraw Hill, New York.

45 Committee for Economic Development (1971) Social Responsibilities of Business Corporations, Committee for Economic Development, New York. Represented non-concentrically in order to coherently display the text.

46 Davis, K. and Blomstrom, R.L. (1975) Business and Society: Environment and Responsibility, 3rd ed., McGraw-Hill, New York.

47 Carroll, A.B. (1979) 'A three-dimensional conceptual model of corporate social performance', Academy of Management Review, Vol. 4, No. 4, p.497.

48 Silberhorn, D. and Warren, R. (2007) 'Defining corporate social responsibility: a view from big companies in Germany and the UK', European Business Review, Vol. 19, No. 5, p.352.

49 Silberhorn, D. and Warren, R. (2007) 'Defining corporate social responsibility: a view from big companies in Germany and the UK', European Business Review, Vol. 19, No. 5, p.352.

50 Pinkston, T.S. and Carroll, A.B. (1996) 'A retrospective examination of CSR orientations. Have they changed?', Journal of Business Ethics, Vol. 15, No. 2, p.199.

51 Pinkston, T.S. and Carroll, A.B. (1996) 'A retrospective examination of CSR orientations. Have they changed?', Journal of Business Ethics, Vol. 15, No. 2, p.199.

52 O'Dwyer, B. (2003) 'Conceptions of corporate social responsibility: the nature of managerial capture', Accounting, Auditing \& Accountability Journal, Vol. 16, No. 4, p.523.

53 Pinkston, T.S. and Carroll, A.B. (1996) 'A retrospective examination of CSR orientations. Have they changed?', Journal of Business Ethics, Vol. 15, No. 2, p.199.

54 Levy, F. and Shatto, G. (1980) 'Social responsibility in large electric utility firms: the case of philanthropy', in Preston, L.E. (Ed.): Research in Corporate Social Performance and Policy, Vol. 1, JAI Press, Greenwich.

55 Facebook, Welcome to Facebook [online] https://www.facebook.com/ (accessed 17 April 2013).

56 The Guardian, Waitrose Halts Plans to Expand Shell Partnership [online] http://www. guardian.co.uk/environment/2012/dec/13/waitrose-plans-shell-partnership (accessed 17 April 2013). 
57 Friends of the Earth, Behind the Shine: The Other Shell Report [online] http://www.foe.co.uk/ resource/reports/behind_shine.pdf (accessed 3 January 2013).

58 Unilever, Purpose and Principles [online] http://www.unilever.co.uk/aboutus/ purposeandprinciples/ (accessed 17 April 2013).

59 Unilever, Unilever Sustainable Living Plan: Progress Report 2011 [online] http://www. unilever.com/images/uslp-Unilever_Sustainable_Living_Plan_Progress_Report_2011_tcm13284779.pdf (accessed 17 April 2013).

60 Lifebuoy, Lifebuoy [online] http://www.lifebuoy.com/ (accessed 17 April 2013).

61 Pureit, Pureit [online] http://www.pureitwater.com/IN/ (accessed 17 April 2013).

62 Fairtrade Foundation, What is Fairtrade? [online] http://www.fairtrade.org.uk/what_is_ fairtrade/default.aspx (accessed 17 April 2013).

63 Unilever, Unilever Sustainable Living Plan: Progress Report 2011 [online] http://www. unilever.com/images/uslp-Unilever_Sustainable_Living_Plan_Progress_Report_2011_tcm13284779.pdf (accessed 17 April 2013) at p.6.

64 Unilever, Unilever Sustainable Living Plan: Progress Report 2011 [online] http://www. unilever.com/images/uslp-Unilever_Sustainable_Living_Plan_Progress_Report_2011_tcm13284779.pdf (accessed 17 April 2013) at p.6.

65 Unilever, Unilever Sustainable Living Plan: Progress Report 2011 [online] http://www. unilever.com/images/uslp-Unilever_Sustainable_Living_Plan_Progress_Report_2011_tcm13284779.pdf (accessed 17 April 2013) at p.6.

66 Unilever, Unilever Sustainable Living Plan: Progress Report 2011 [online] http://www. unilever.com/images/uslp-Unilever_Sustainable_Living_Plan_Progress_Report_2011_tcm13284779.pdf (accessed 17 April 2013).

67 Unilever, Unilever Sustainable Living Plan: Progress Report 2011 [online] http://www. unilever.com/images/uslp-Unilever_Sustainable_Living_Plan_Progress_Report_2011_tcm13284779.pdf (accessed 17 April 2013) at p.3.

68 Unilever, Unilever Sustainable Living Plan [online] http://www.unilever.com/images/ UnileverSustainableLivingPlan_tcm13-284876.pdf (accessed 17 April 2013).

69 Ankerman, R.W. and Bauer, R.A. (1976) Corporate Social Responsiveness, Reston Publishing, Virginia.

70 For example, the European CSR award scheme: Business in the Community, About European CSR Award Scheme [online] http://www.bitc.org.uk/international/awards/european-csr-award/ about-european-csr-award (accessed 17 April 2013).

71 Unilever, Awards and Recognition [online] http://www.unilever.com/sustainable-living/ ourapproach/awards/ (accessed 17 April 2013).

72 Ankerman, R.W. and Bauer, R.A. (1976) Corporate Social Responsiveness, Reston Publishing, Virginia. 